\title{
Use of Digital Media for Sex Education in Early Childhood with Low-Income Parents
}

\author{
Susianty Selaras Ndari ${ }^{1 *}$, Khusniyati Masykuroh², Amelia Vinayastri ${ }^{3}$, Kibitiah $^{4}$ \\ Universitas Muhammadiyah Prof. DR. HAMKA, Indonesia
}

This study aims to explore the use of digital smartphone media for sexuality education of children with low-income parents by emphasizing the usage of digital media for protection from sexual violence against children. This research method uses case studies with children (aged 3-6 years) in 25 low-income families. Data collection was carried out for eight rounds using an ecocultural approach to examine the experiences of children and parents in using digital media technology for sex education for children aged 3-6 years. This research explains 1) What technology is used by children at home ?, 2) what is the role of parents at home in helping children in providing sex education learning using digital media ?, 3) What are the benefits of using digital media for sex? education for children? This is done because of the adaptation of technology to the curriculum for early childhood education. Due to the increasing use of digital media in all layers of parents, so the use of digital technology can help

OPEN ACCESS ISSN 2579-5813 (online)

Edited by: Nurdyansyah

Reviewed by: Mu`alimin Mu`alimin ${ }^{\star}$ Correspondence: Susianty Selaras Ndari susilaras@uhamka.ac.id

Received:5 Februari 2021 Accepted: 15 Maret 2021 Published:30 April 2021

Citation:

Ndari SS, Masykuroh K, Vinayastri A, and Kibitiah (2021) Use of Digital Media for Sex Education in Early Childhood with Low-Income Parents. Madrosatuna: Journal of Islamic Elementary School. 5:1. doi: children to learn to increase their knowledge of sexuality. So they can protect themselves from sexual violence.

\footnotetext{
Keywords: Digital Media, Sex Education, Early Childhood, Low Income
} 


\section{INTRODUCTION}

The use of digital media through digital devices shows a collaboration between children and teachers in the class when operating, touching, pressing, Sharkins et al. (2015) and understanding images and answering teacher questions related to animated pictures that are displayed form fun learning activities. Using mobile digital media has more positive advantages for learning in schools, Jhonson et al. (2009); Radesky et al. (2014); Setyawan (2014) and is often marketed as an additional learning tool for children. Soderman et al. (1982); Kostelnik (1988). The use of digital media includes mp3 players, iPods, iPads, gaming applications, and televisions, including laptops Galetzka (2017); Fider (2019), mobile media, tablets, and other touch screens. At present, the mobile devices used are 9.6 billion compared to the current 7.4 billion people on Earth. It is further projected that by the end of 2018, the number of cellphone users worldwide is expected to exceed 6.2 billion. That is, around $84 \%$ of the world's population Sharkins et al. (2015); Ernest et al. (2019), parents and teachers continue to introduce digital media devices in the lives of children. Research shows $41 \%$ of parents give children a handheld telephone device while in a restaurant, and $78 \%$ of parents report no problem while providing a mobile phone device to a child. Setyawan (2014)

In 2004-2009 Children aged 2-11 years spent 63\% time on the Internet Hoffman et al. (2013). Soderman et al. (1982); Kostelnik (1988) Also, 10\% of children aged 4-5 years have their mobile phones. (30\% of children aged 6-9 years) have their cellphones or digital music players Cagiltay et al. (2013); Kara et al. (2012). for this reason, they need to study the effect of digital media on children's learning becomes increasingly important in efforts to maximize learning. A study examining the prevalence of iPods in classrooms, for example, found that early childhood educators in all programs and reported student income levels nearly doubled the increase in tablet access 2012-2014. Cagiltay et al. (2013) Meanwhile, research reports that when learning memory in early childhood twice increased. One of the benefits of using interactive media is to enrich the atmosphere of the learning environment, enhance fantasy and interaction. Kara et al. (2012) Other results show that the use of digital media can improve children's cognitive and social intelligence (Ilene and Michael), increase social interaction of children aged three to five years Sharkins et al. (2015), can expand children's knowledge, Ernest et al. (2019) improving language skills and literacy (Paciga, 2013) Besides the use of digital media which presents a merging of actual virtual and physical images. Cagiltay et al. (2013) It can be interpreted based on the statement that digital games can be used for educational purposes. In learning, children build experiences through virtual content and imagination. Therefore, children can improve playing skills to achieve the goals of education. Kara et al.(2012) However, children's cognitive development is unable to keep up with the speed of digital media so interaction is needed with the environment so that children's cognitive development can increase Radesky et al. (2014), Zimmerman et al. (1971); Galetzka (2017), so in the use of digital media at home parents need to assist their children.
Some research results show the increasing use of digital media in children. This provides an excellent opportunity for teachers in kindergarten in carrying out sexuality education for low-income parents because widespread use in all walks of life is no exception for low-income parents in South Jakarta. The increasing use of digital media is the modality of educators in teaching and learning activities to be more effective, especially for children's sexuality knowledge. Knowledge of sexuality is taught to children so that children have the knowledge and skills in self-protection from sexual violence. Sexual child victims have the potential to experience long-term trauma such as; abuse at home, risky sexual behavior (especially in adolescence), post-traumatic stress disorder, emotional dysregulation TNTCSN (2009); Walker (2006), and sexually abusive behavior as adults. Childhood difficulties undergoing childhood, aggression, antisociality, and unfocused response, childhood experiences as victims of sexual violence result in children behaving antisocial behavior, the accumulation of early trauma increases the likelihood of opportunities and strengthens the child's potential to behavior criminal. Meanwhile, sexuality education for children is still a taboo for some people, so that there are obstacles in providing sexuality education. Aspects of culture that taboo Sexuality education results in barriers to interaction between adults and children. Meanwhile, research shows that sexuality education in children is still a taboo for some people, so that there are obstacles in providing sexuality education need to look for a universal dimension in the themes of Sksuality Education in children. Walker (2006)

Children learn through play; therefore, sexuality education is carried out by playing using digital media smartphones; children are actively involved and fun in learning sexuality so that they know of self-protection from sexual violence. This research also provides information to teachers and parents that the use of digital smartphone media is effectively used as a medium for learning sexuality knowledge in kindergarten children.

\section{METHOD}

The research method was conducted by observation to observe complex interactions that occur between peers, family members, digital media technology, and other toys found in families for sex education in children aged 3-6 years, through the cultural environment approach in the family. The documentation notes contain children's interviews about favorite toys, parents' perceptions about the use of digital media technology for child sex education, and interviews about transition changes about the benefits of using digital media for sex education in children aged 3-6 years. Multidimensional analysis is carried out through approaches from various sources originating from the family environment, children's perceptions, and from other family members, playing activities using digital media technology for sex education in children. Analysis of textual data using $\mathrm{N}$ Vivo. 


\section{RESULT AND DISCUSSION}

TABLE 1 | A Case Study of Tolerance for The Use of Digital Media for Early Childhood Education

\begin{tabular}{|c|c|c|c|c|c|}
\hline No. & $\begin{array}{l}\text { Initials } \\
\text { Name }\end{array}$ & Gender & $\begin{array}{l}\text { Social } \\
\text { Economic } \\
\text { Status }\end{array}$ & $\begin{array}{l}\text { Use of } \\
\text { Technology }\end{array}$ & $\begin{array}{l}\text { Attitude } \\
\text { Towards Use } \\
\text { of Digital } \\
\text { Media }\end{array}$ \\
\hline 1 & $A L Y$ & FM & High & tigh & $\begin{array}{l}\text { Good, With } \\
\text { Supervision }\end{array}$ \\
\hline 2 & PK & FM & High & tigh & $\begin{array}{l}\text { Good, With } \\
\text { Supervision }\end{array}$ \\
\hline 3 & $\mathrm{KN}$ & FM & High & tigh & $\begin{array}{l}\text { Good, With } \\
\text { Supervision }\end{array}$ \\
\hline 4 & KK & FM & High & tigh & $\begin{array}{l}\text { Good, With } \\
\text { Supervision }\end{array}$ \\
\hline 5 & Al & FM & High & tigh & $\begin{array}{l}\text { Refuse, Not } \\
\text { Safe for } \\
\text { Children }\end{array}$ \\
\hline 6 & DN & FM & High & tigh & $\begin{array}{l}\text { Good, With } \\
\text { Supervision }\end{array}$ \\
\hline 7 & MY & FM & High & tigh & $\begin{array}{l}\text { Good, No } \\
\text { Appearance }\end{array}$ \\
\hline 8 & LS & $\mathrm{FM}$ & Low & tigh & $\begin{array}{l}\text { Good, With } \\
\text { Supervision }\end{array}$ \\
\hline 9 & GR & $M$ & Low & tigh & $\begin{array}{l}\text { Good, With } \\
\text { Supervision }\end{array}$ \\
\hline 10 & $\mathrm{HN}$ & $M$ & Low & -ow & $\begin{array}{l}\text { Good, With } \\
\text { Supervision }\end{array}$ \\
\hline 11 & ZKY & $M$ & Low & tigh & $\begin{array}{l}\text { Good, With } \\
\text { Supervision }\end{array}$ \\
\hline 12 & FAT & $M$ & Low & tigh & $\begin{array}{l}\text { Good, With } \\
\text { Supervision }\end{array}$ \\
\hline 13 & $A L$ & $\mathrm{M}$ & Low & tigh & $\begin{array}{l}\text { Good, With } \\
\text { Supervision }\end{array}$ \\
\hline 14 & BM & $\mathrm{M}$ & Low & tigh & $\begin{array}{l}\text { Good, With } \\
\text { Supervision }\end{array}$ \\
\hline 15 & DR & $\mathrm{M}$ & Low & tigh & $\begin{array}{l}\text { Good, With } \\
\text { Supervision }\end{array}$ \\
\hline 16 & $\mathrm{BON}$ & $M$ & Low & tigh & $\begin{array}{l}\text { Good, With } \\
\text { Supervision }\end{array}$ \\
\hline 17 & GN & $\mathrm{M}$ & Low & tigh & $\begin{array}{l}\text { Refuse, Not } \\
\text { Safe for } \\
\text { Children }\end{array}$ \\
\hline 18 & $\mathrm{ZH}$ & $\mathrm{M}$ & Low & tigh & $\begin{array}{l}\text { Good, With } \\
\text { Supervision }\end{array}$ \\
\hline 19 & $\mathrm{KX}$ & $M$ & Low & tigh & $\begin{array}{l}\text { Refuse, Not } \\
\text { Safe for } \\
\text { Children }\end{array}$ \\
\hline 20 & GUN & $\mathrm{M}$ & Low & .ow & $\begin{array}{l}\text { Good, With } \\
\text { Supervision }\end{array}$ \\
\hline 21 & $\mathrm{HW}$ & $M$ & Low & tigh & $\begin{array}{l}\text { Good, No } \\
\text { Appearance }\end{array}$ \\
\hline 22 & $\mathrm{HH}$ & $M$ & Low & tigh & $\begin{array}{l}\text { Good, With } \\
\text { Supervision }\end{array}$ \\
\hline 23 & YAN & FM & Low & tigh & $\begin{array}{l}\text { Refuse, Not } \\
\text { Safe for } \\
\text { Children }\end{array}$ \\
\hline 24 & JUM & FM & Low & tigh & $\begin{array}{l}\text { Good, With } \\
\text { Supervision }\end{array}$ \\
\hline 25 & $\mathrm{RA}$ & FM & Low & tigh & $\begin{array}{l}\text { Good, No } \\
\text { Appearance }\end{array}$ \\
\hline
\end{tabular}

\section{Technology used by children at home}

Digital media technology found in this study is smartphone technology used by parents at home to study sex education in early childhood 3-6 years. Ownership of technology by parents does not guarantee that children can access it, citing insecurity, because of the negative effects it causes. This refers to the data collected, which refers to the ownership of digital smartphone media technology that is obtained every visit to the home. The results of the study found that two families use computers as digital media technology for sex education in children aged 3-6 years. Twenty-three parents use smartphones as the use of digital media technology for sex education in children. Two families have access to his wife at home, and one family uses a computer.

\section{The role of parents in assisting the use of digital media for sex education in early childhood 3-6 years}

Data on 18 families with low economic status were actively accessing smartphones using digital media technology for sex education in children. Parents' perception of the use of digital media technology is excellent but with supervision. Also, the use of digital media techniques is closer to the relationship between parents and children, maximizing the quality of care even when activities take place between children and siblings who want to engage in play activities using digital smartphone media. The data shows one family with high economic status, and high technology ownership rejects the use of digital media technology for sex education in children, citing insecurity for children and the negative impact arising from the use of smartphones. Furthermore, the data succeeded in showing three families of low economic status and high technology ownership rejecting the usage of digital media technology for sex education in children on the grounds of being unsafe for children and the negative impacts arising from the use of smartphones.

\section{The benefits of sex education in early childhood 3-6 years using digital media}

The research data obtained by the perception of 18 families who access the use of digital media for sex education in early childhood 3-6 years shows that digital media technology provides significant benefits for sex education in children. Children show interest and interest when parents allow them to access a parent's smartphone for sex education at home. The use of digital media technology makes it easy for sex education to be understood by children in every dimension namely; 1) Knowledge of recognizing gender identity and roles, 2) Knowledge of sexuality organs, 3) Knowledge of maintaining genital/toilet training, 4) Knowledge of abstaining from sexual crimes and 5) Knowledge of reproduction. Soderman et al. (1982) In a study conducted by the researchers, the five dimensions of sex education in children were in the form of animated videos that were input into each parent's smartphone, so that parents could easily play with their children. An example of visualization of the dimensions of a sex education video prepared, with sound/dubbing accompanied by text, then installed into digital smartphone media technology, as shown in figures 1 to 7.

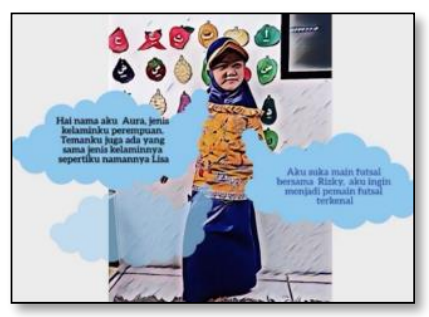

Figure 1 | Knowledge of Gender Identity and Roles 


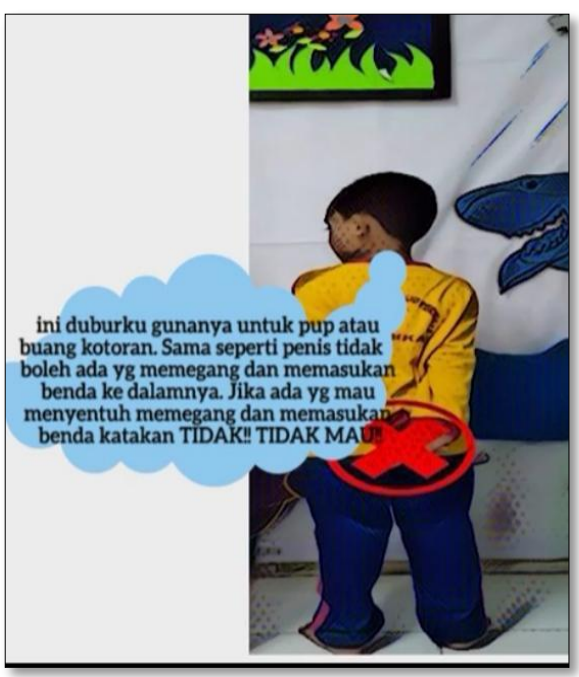

Figure 2 | Knowledge of the Organs of Sexuality

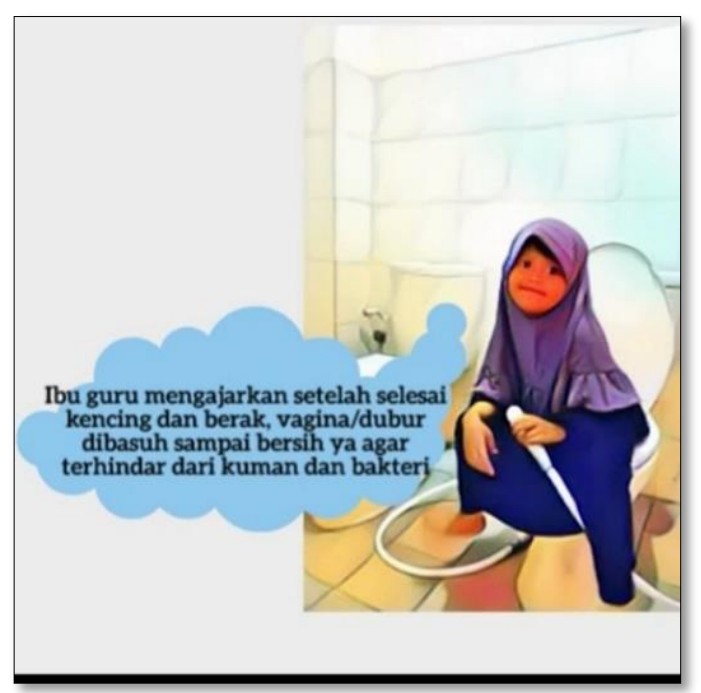

Figure 3 | Training on Cleaning Tools about Genitals/Toilets

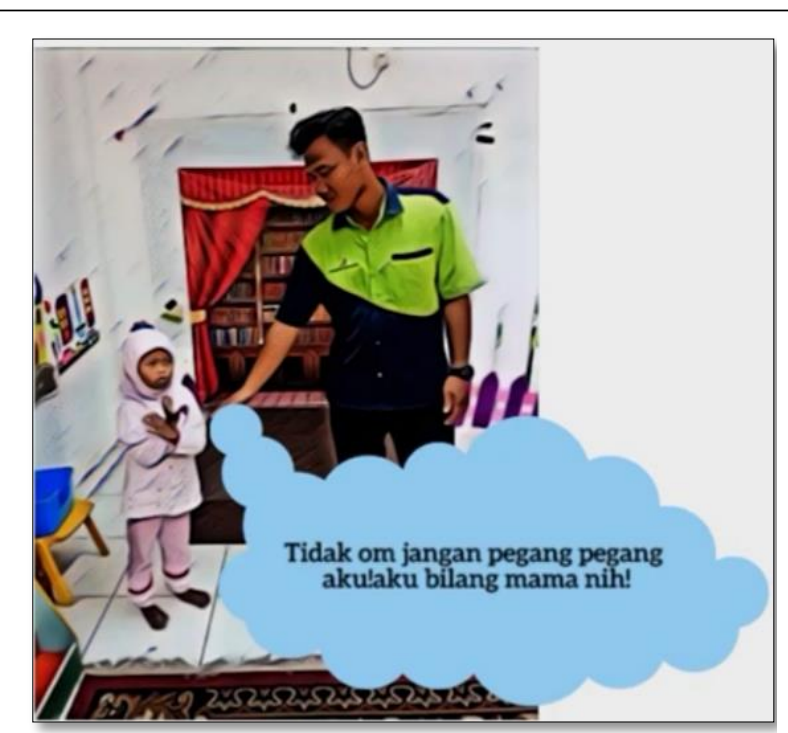

Figure 4 | Knowledge of Abstaining from Sexual Crimes

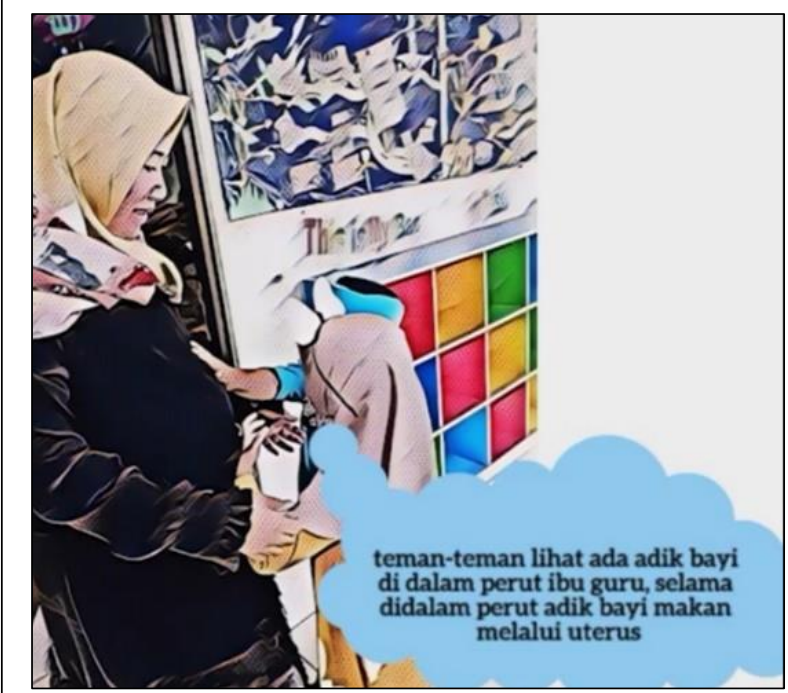

Figure 5 | Dimensions of Knowledge about Human Reproduction

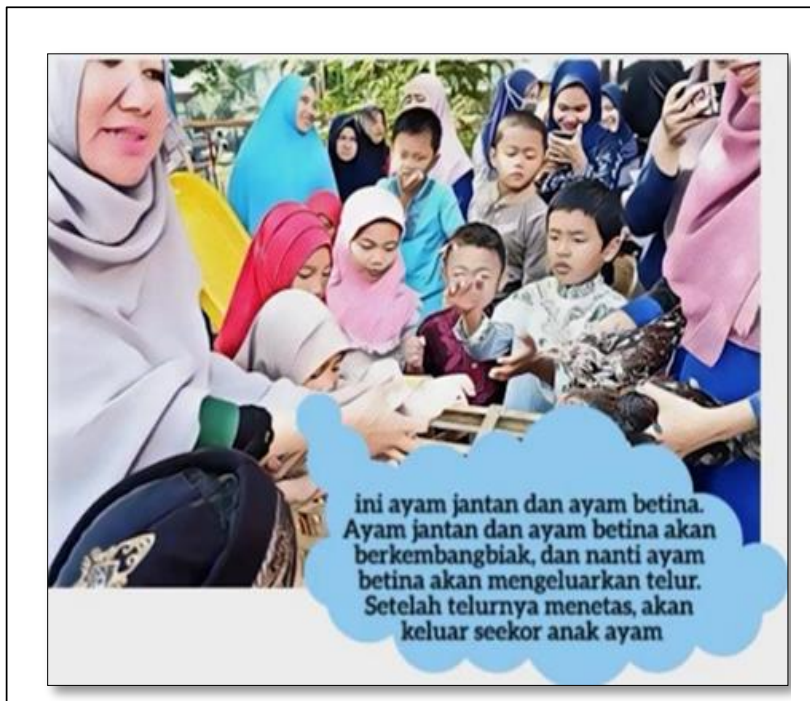

Figure 6 | Dimensions of Knowledge about Animal Reproduction

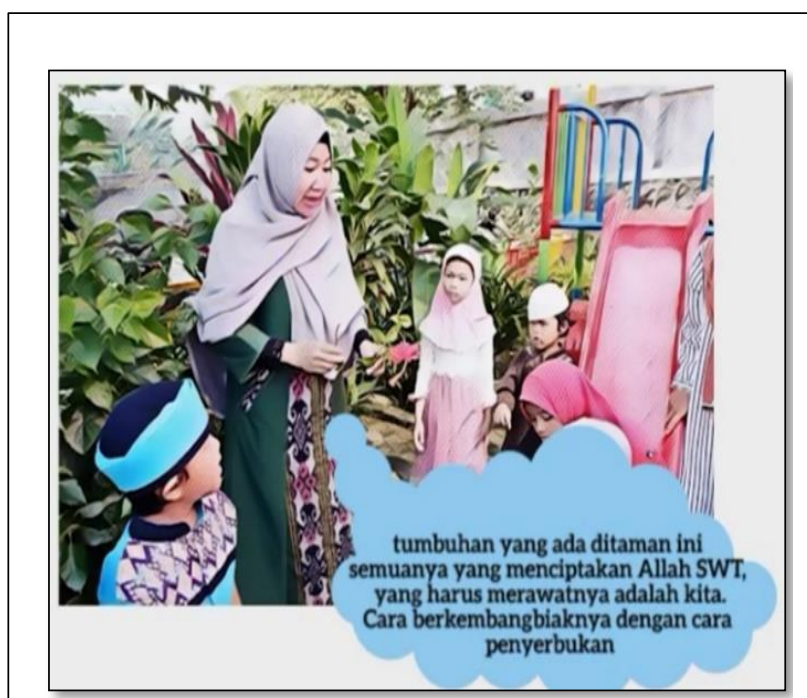

Figure 7 | Dimensions of Knowledge about Plant Reproduction 
Understanding the role of digital media technology for overall child sex education shows significant results. Smartphones are used to support children to be patient, diligently using smartphones during activities so that they can control and manage children's emotions. In the context of the family, digital smartphone media technology for child sex education can increase parental involvement in care so that it attaches emotions between children and parents. When the activity takes place, children learn to share smartphones with siblings. It can be understood that the use of digital media can increase collaboration between children Chen (2019); Lieberman et al. (2009).

Based on the results of interviews of parents' perceptions and children's attitudes, shows that the use of digital media technology for sex education in children aged 3-6 years there are five dimensions, namely; 1) Knowledge recognizes gender identity and roles, 2) Knowledge of sexuality organs, 3) Knowledge of genital/toilet maintenance, 4) Knowledge of distance from sexual crimes and 5) Reproductive knowledge. The results showed an opportunity for parents to prepare children to provide sex education as a condition of self-protection from sexual violence and experiences for the next life. Because it currently shows children faced with a situation of technological progress Jhonson et al. (2009), children now grow up in the digital world. Prensky (2003) Digital children who face the world can be used for learning, especially sex education, for children aged 3-6 years

\section{CONCLUSION}

The ecocultural approach can provide convenience in retrieving data from various sources about the use of digital smartphone media technology for sex education for children aged 3-6 years for low-income parents in Cilandak District, South Jakarta. Researchers analyzed the interactions that occur in people in families, places, and new findings, along with the values and attitudes of parents, appear significant. Ecocultural studies are appropriate to identify the use of smartphone media technology for sex education in children aged 3-6 years by maximizing available resources. The support offered shows that the successful use of smartphone digital media technology for sex education for children aged 3-6 years depends on local environmental conditions.

\section{REFRENCES}

A. K. Soderman, M. J. Kostelnik, B. D. Ames, and L. A. Phenice, "Child Nurturance: Patterns of Supplementary Parenting," Patterns of Supplementary Parenting. Springer US, pp. 3-31, 1982.

C. Galetzka, "Commentary: Mobile and interactive media use by young children: The good, the bad, and the unknown," Front. Psychol., vol. 8, no. MAR, pp. 8$10,2017$.

C. Galetzka, "Commentary: Mobile and Interactive Media Use by Young Children: The Good, the Bad, and the Unknown," Front. Psychol., vol. 8, 2017.

C. O. Fider and S. Q. Olaoshebikan, "An Analysis on Mobile and Interactive Media Use by Young Children: The Good, the Bad and the Unknown," Child. Teenagers, vol. 2, no. 2, p. p89, 2019.

D. A. Lieberman, C. H. Bates, and J. So, "Young Children's Learning With Digital Media," Comput. Sch., vol. 26, no. 4, pp. 271-283, 2009.

J. E. Johnson and J. F. Christie, "Play and Digital Media," Comput. Sch., vol. 26, no. 4, pp. 284-289, 2009.

J. L. Hoffman, W. H. Teale, and K. A. Paciga, "Assessing vocabulary learning in early childhood,” J. Early Child. Lit., vol. 14, no. 4, pp. 459-481, 2013.

J. M. Ernest, C. Causey, A. B. Newton, K. Sharkins, J. Summerlin, and N. Albaiz, "Extending the Global Dialogue About Media, Technology, Screen Time, and Young Children," Child. Educ., vol. 90, no. 3, pp. 182-191, 2014.

J. S. Radesky, J. Schumacher, and B. Zuckerman, "Mobile and Interactive Media Use by Young Children: The Good, the Bad, and the Unknown," Pediatrics, vol. 135, no. 1, pp. 1-3, 2014.

J. Walker and J. Milton, "Teachers' and parents' roles in the sexuality education of primary school children: a comparison of experiences in Leeds, UK and in Sydney, Australia," Sex Educ., vol. 6, no. 4, pp. 415-428, 2006.

K. A. Sharkins, A. B. Newton, N. E. A. Albaiz, and J. M. Ernest, "Preschool Children's Exposure to Media, Technology, and Screen Time: Perspectives of Caregivers from Three Early Childcare Settings," Early Child. Educ. J., vol. 44, no. 5 , pp. $437-444,2015$.

K. Cagiltay, N. Kara, and C. C. Aydin, "Smart Toy Based Learning," Handbook of Research on Educational Communications and Technology. Springer New York, pp. 703-711, 2013.

L. D. Zimmerman and G. Calovini, "Toys as Learning Materials for Preschool Children," Except. Child., vol. 37, no. 9, pp. 642-654, 1971.

M. Chen, "Children and families in the digital age: learning together in a media saturated world," J. Child. Media, pp. 1-4, 2019.

M. J. Kostelnik, L. C. Stein, and A. P. Whiren, "Children's Self-Esteem: The Verbal Environment," Child. Educ., vol. 65, no. 1, pp. 29-32, 1988.

M. Prensky, "Digital game-based learning," Comput. Entertain., vol. 1, no. 1, p. 21, 2003.

N. Kara, C. C. Aydin, and K. Cagiltay, "Design and development of a smart storytelling toy,” Interact. Learn. Environ., vol. 22, no. 3, pp. 288-297, 2012.

The National Child Traumatic Stress Network "Understanding and Coping with Sexual Behavior Problems in Children," PsycEXTRA Dataset. American Psychological Association (APA), 2009.

W. H Setyawan et al., "Challenged Solving in Listening Through T-Mobile Learning Model,” Int. J. Eng. Technol., vol. 7, no. 4.15, p. 443, 2018.

Conflict of Interest Statement: The authors declare that the research was conducted in the absence of any commercial or financial relationships that could be construed as a potential conflict of interest.

Copyright $@ 2021$ Ndari, Masykuroh, Vinayastri, and Kibitiah. This is anopen-access article distributed under the terms of the Creative Commons Attribution License (CC $B Y)$. The use, distribution or reproduction in other forums is permitted, provided the origi- nal author(s) and the copyright owner(s) are credited and that the original publication in this journal is cited, in accordance with accepted academic practice. No use, distri- bution or reproduction is permitted which does not comply with these terms 